\title{
Keefektifan desain pembelajaran ELPSA (experiences, language, pictorial, symbols, application) ditinjau dari hasil belajar matematika siswa pada materi relasi dan fungsi
}

\section{Riska Dwi Setiawati ${ }^{*}$, Nyoman Sridana ${ }^{2}$, Baidowi², Laila Hayati ${ }^{2}$}

\author{
${ }^{1}$ Mahasiswa Pendidikan Matematika, FKIP, Universitas Mataram, Mataram \\ 2 Pendidikan Matematika, FKIP, Universitas Mataram, Mataram
}

riskadwisetiawati11@gmail.com

Diterima: 8 Juni 2021; Direvisi: 26 Juni 2021; Dipublikasi: 30 Juni 2021

\begin{abstract}
This research aims to determine the effectiveness of the ELPSA (Experiences, Language, Pictorial, Symbols, Application) learning design in terms of the mathematics learning outcomes at VIII grade student of SMPN 1 Utan on the material relations and functions in the academic year 2020/2021. The type of this research is experimental research with posttest only design. The research was conducted in 4 meetings with 3 meetings for the learning process using all ELPSA components and 1 meeting for the implementation of the posttest. The samples were determined by using cluster random sampling technique. The sample is class VIII-1A as an experimental class which is given treatment using the ELPSA learning design. Data collection using observation and test techniques. Instruments include: observation sheets and learning outcomes tests. Learning outcome data is used to find out how far students understand the material being taught and observation data is used to determine the implementation of learning which is analyzed descriptively. Indicators of the effectiveness of the ELPSA learning design, namely if student learning outcomes with a percentage of classical learning completeness of $\geq 85 \%$. The results showed that there were 14 students who had completed their studies or equal to $87,50 \%$ and 2 students who did not complete their studies or $12,50 \%$ with an average grade obtained of 82,38 . The results of observations of student with active criteria with a percentage of $74 \%$ and teacher activities with good criteria with a percentage of $71 \%$.
\end{abstract}

Keywords: Experiment; Posttest; Cluster Random Sampling; Student Activity; Teacher Activity

\begin{abstract}
Abstrak
Penelitian ini bertujuan untuk mengetahui keefektifan desain pembelajaran ELPSA (Experiences, Language, Pictorial, Symbols, Application) ditinjau dari hasil belajar matematika siswa kelas VIII SMPN 1 Utan pada materi relasi dan fungsi tahun pelajaran 2020/2021. Jenis penelitian yang digunakan adalah penelitian eksperimen dengan desain posttest only design. Penelitian dilaksanakan dalam 4 kali pertemuan dengan 3 kali pertemuan untuk proses pembelajaran menggunakan semua komponen ELPSA dan 1 kali pertemuan untuk pelaksanaan posttest. Penentuan sampel dilakukan dengan teknik cluster random sampling. Sampel adalah kelas VIII-1A sebagai kelas eksperimen yang diberikan perlakuan menggunakan desain pembelajaran ELPSA. Pengumpulan data dengan teknik tes dan observasi. Instrumen meliputi: tes hasil belajar dan lembar observasi. Data hasil belajar digunakan untuk mengetahui seberapa jauh pemahaman siswa terhadap materi yang diajarkan dan data hasil observasi digunakan untuk mengetahui keterlaksanaan pembelajaran yang dianalisis secara deskriptif. Indikator keefektifan desain pembelajaran ELPSA yaitu jika hasil belajar siswa dengan persentase ketuntasan belajar klasikal $\geq 85 \%$. Hasil penelitian menunjukkan bahwa terdapat 14 siswa yang telah tuntas belajarnya atau sebesar 87,50\% dan 2 siswa yang tidak tuntas belajarnya atau sebesar $12,50 \%$ dengan rata-rata nilai yang diperoleh sebesar 82,38 . Hasil observasi aktivitas siswa berkriteria aktif dengan persentase yaitu $74 \%$ dan aktivitas guru berkriteria baik dengan persentase yaitu $71 \%$.
\end{abstract}

Kata Kunci: Eksperimen; Posttest; Cluster Random Sampling; Aktivitas Siswa; Aktivitas Guru 


\section{PENDAHULUAN}

Paparkan masalah yang dikaji, diakhiri dengan menjelaskan tujuan dan urgensi penelitian. Empat poin penting yang wajib ada dalam pendahuluan adalah menguraikan secara jelas tentang (secara berurutan): (1) sedikit latar belakang umum kajian; (2) state of the art (kajian review literatur singkat) penelitian-penelitian dan penelitian-penelitian sebelumnya (yang mirip) untuk menjustifikasi novelty artikel yang dibuat; (3) gap analysis atau pernyataan kesenjangan (orisinalitas) atau kebaruan (novelty statement) atau beda unik penelitian ini dibanding penelitian-penelitian sebelumnya atau berdasarkan state of the art (dari sisi penting tidaknya penelitian serta perbandingan keunikan dengan penelitian sebelumnya); cara pendekatan penyelesaian masalah (jika ada); (4) hasil yang diharapkan atau tujuan penelitian. Bagian isi makalah ditulis dengan font Century Schoolbook dengan ukuran tulisan 11pt dan spasi 1.15 .

Saat ini, di dunia sedang terjadi wabah Coronavirus Diseases 2019 (COVID-19) yang berdampak bagi seluruh masyarakat dunia termasuk Indonesia. Dampak virus COVID19 terjadi di berbagai bidang salah satunya bidang pendidikan. Pada tanggal 24 maret 2020 Menteri Pendidikan dan Kebudayaan Republik Indonesia mengeluarkan Surat Edaran Nomor 4 Tahun 2020 yang berisikan proses belajar dilaksanakan di rumah melalui pembelajaran daring/jarak jauh untuk memberikan pengalaman belajar bagi siswa (Dewi, 2020).

Berdasarkan hasil wawancara guru matematika yang dilakukan tanggal 29 Juli 2020 di SMPN 1 Utan diperoleh informasi bahwa sekolah melakukan pembelajaran daring melalui aplikasi google classroom dan juga whatsapp group. Akan tetapi, ada beberapa masalah yang muncul saat guru melakukan pembelajaran daring yaitu guru kesulitan dalam menyampaikan materi pelajaran dan guru tidak mengetahui apakah siswa sudah paham atau belum mengenai materi yang telah diberikan. Permasalahanpermasalahan ini berdampak pada rendahnya hasil belajar matematika siswa. Hal ini dapat dilihat dari rata-rata nilai dan ketuntasan klasikal ulangan harian semester genap siswa kelas VII tahun pelajaran 2019/2020 pada pelajaran matematika, dimana rata-rata nilai siswa masih di bawah Kriteria Ketuntasan Minimum (KKM) yang telah ditetapkan sekolah yaitu 68 untuk KKM mata pelajaran matematika.

Tabel 1. Rata-Rata Nilai dan Ketuntasan Klasikal Ulangan Harian Siswa Kelas VII

\begin{tabular}{cccc}
\hline Kelas & Jumlah Siswa & Rata-Rata Nilai & Ketuntasan Klasikal \\
\hline VII 1 & 32 & 66,80 & 50,00 \\
VII 2 & 33 & 62,70 & 36,36 \\
VII 3 & 33 & 65,80 & 45,45 \\
VII 4 & 32 & 67,50 & 43,75 \\
VII 5 & 34 & 63,00 & 32,35 \\
VII 6 & 34 & 63,50 & 38,26 \\
\hline
\end{tabular}


Faktor penyebab rendahnya hasil belajar siswa bukan hanya disebabkan oleh siswa, melainkan juga faktor dari guru. Strategi mengajar, model pembelajaran dan desain pembelajaran yang tepat pada dasarnya bertujuan untuk menciptakan kondisi pembelajaran yang memungkinkan siswa dapat belajar secara aktif sehingga siswa dapat meraih prestasi belajar dengan optimal (Baidowi, Hikmah, \& Amrullah, 2019). Akan tetapi, saat pembelajaran berlangsung biasanya guru hanya memberikan informasi tentang mata pelajaran matematika setelah itu memberikan soal-soal untuk dikerjakan oleh siswa. Pembelajaran seperti itu membuat siswa lemah dalam pembentukan konsep yang mengarah pada pemahamannya sehingga siswa lebih banyak menghafal dan mengakibatkan rendahnya hasil belajar.

Berdasarkan permasalahan yang dikemukakan di atas, perlu adanya desain pembelajaran yang diharapkan akan lebih memudahkan proses belajar mengajar khususnya pelajaran matematika yang menarik sehingga dapat meningkatkan hasil belajar siswa. Oleh karena itu, peneliti akan mencoba menerapkan desain pembelajaran ELPSA (Experience, Language, Pictorial, Symbols, Application) yang diharapkan mampu membuat siswa menghadirkan idenya sendiri sehingga dapat meningkatkan hasil belajar matematikanya.

ELPSA merupakan sebuah kerangka desain pembelajaran singkatan dari Experiences, Language, Pictorial, Symbols, dan Application yang diketuai oleh Prof. Tom Lowrie dari Charles Sturt University Australia. ELPSA didasarkan pada teori-teori pembelajaran konstruktivisme dan sifatnya sosial. Desain pembelajaran ELPSA melihat pembelajaran sebagai suatu proses aktif dimana siswa mengkonstruksi sendiri caranya dalam memahami sesuatu melalui proses berpikir secara individu dan interaksi sosial dengan orang lain (Lowrie \& Patahuddin, 2015).

Langkah-langkah pembelajaran ELPSA terdiri atas 5 komponen yaitu E (Experiences/pengalaman), pada komponen ini guru perlu memastikan pengetahuan yang dimiliki siswa berkaitan dengan materi yang akan dipelajari. L (Language/bahasa), komponen ini fokus pada bahasa/istilah spesifik yang digunakan guru untuk menyajikan ide/konsep matematika. Bahasa juga dapat muncul ketika siswa menggunakan bahasa umum maupun spesifik untuk membantu mengklarifikasi ide-ide tentang suatu konsep. Penyajian guru, representasi dalam bentuk model, alat peraga, gambar, grafik, diagram, pola, dan tabel digunakan untuk membantu siswa memaknai/memahami hubungan antar konsep dalam matematika menuju ke simbol yang lebih abstrak, bagian ini disebut $\mathrm{P}$ (Pictorial/gambar). Komponen $\mathrm{S}$ (Symbols/simbol) melibatkan siswa dalam penyajian, mengkonstruksi, dan memanipulasi informasi dalam bentuk simbol. Dan A (Application/aplikasi), pada komponen ini menggunakan konsep-konsep dan ide-ide yang disajikan dalam situasi/masalah baru secara bermakna (Lowrie \& Patahuddin, 2015).

Melalui desain pembelajaran ELPSA ini tentu akan membuat siswa menjadi lebih aktif saat mengikuti pelajaran. Hal ini, diharapkan dapat meningkatkan hasil belajar 
matematika siswa dari sebelumnya. Di SMPN 1 Utan pembelajaran tatap muka sudah dapat dilakukan dengan menerapkan protokol kesehatan Covid-19, ini berarti desain pembelajaran ELPSA dapat diterapkan pada saat pembelajaran matematika di SMPN 1 Utan tahun pelajaran 2020/2021. Berdasarkan penjelasan di atas, peneliti akan melakukan penelitian yang berjudul "Keefektifan Desain Pembelajaran ELPSA (Experiences, Language, Pictorial, Symbols, Application) Ditinjau dari Hasil Belajar Matematika Siswa Kelas VIII SMPN 1 Utan pada Materi Relasi dan Fungsi Tahun Pelajaran 2020/2021".

\section{METODE PELAKSANAAN}

Penelitian ini dilaksanakan pada siswa kelas VIII SMPN 1 Utan pada semester ganjil tahun pelajaran 2020/2021. Penelitian ini merupakan penelitian eksperimen yaitu suatu situasi penelitian yang sekurang-kurangnya satu variabel bebas atau variabel eksperimental (Emzir, 2017). Pendekatan yang digunakan dalam penelitian ini adalah pendekatan kuantitatif yaitu data penelitian berupa angka-angka dan analisis menggunakan statistic (Sugiyono, 2019). Penelitian ini menggunakan desain penelitian posttest only design yang bertujuan untuk menentukan apakah ada perubahan terhadap hasil belajar setelah diberi perlakuan. Hasil belajar yang menggunakan posttest akan dijadikan patokan untuk menarik kesimpulan (Emzir, 2017).

Populasi dalam penelitian ini adalah seluruh siswa kelas VIII SMPN 1 Utan tahun pelajaran 2020/2021 yang terdiri dari 6 kelas. Teknik sampel yang digunakan adalah cluster random sampling. Teknik ini merupakan cara pengambilan sampel kelas secara acak dari kelas-kelas yang sudah ada sebagai suatu populasi (Margono, 2004). Cara pengambilan sampel kelas acak dalam penelitian ini adalah dengan cara undian sederhana. Instrumen penelitian yang digunakan adalah tes berupa soal uraian. Untuk menunjang penelitian ini, dilakukan observasi aktivitas siswa dan guru yang diamati oleh observer (guru mata pelajaran matematika).

Instrumen penelitian yang digunakan tentunya telah memenuhi kriteria valid dan reliabel ditinjau dari uji validitas empiris. Teknik analisis data yang digunakan dalam penelitian ini adalah teknik statistik deskriptif, yaitu statistik yang digunakan untuk menganalisis data dengan cara mendeskripsikan atau menggambarkan data yang telah terkumpul baik itu melalui tabel, grafik, perhitungan mean dan perhitungan persentase (Sugiyono, 2019). Analisis statistik deskriptif digunakan untuk menggambarkan hasil belajar matematika siswa serta aktivitas siswa dan guru. Untuk menggambarkan hasil belajar matematika siswa dapat dilihat dari ketuntasan belajar klasikal yaitu $\geq 85 \%$ yang dihitung dengan menggunakan program Microsoft Excel. Rumus ketuntasan belajar klasikal adalah sebagai berikut (Depdiknas, 2004). 


$$
\text { Ketuntasan Klasikal }=\frac{\text { Jumlah siswa yang tuntas belajar }}{\text { Jumlah siswa seluruhnya }} \times 100 \%
$$

Untuk menggambarkan aktivitas siswa dapat dilihat dari persentase nilai rata-rata yaitu sebagai berikut (Trianto, 2011).

$A S=\frac{\Sigma S}{\Sigma s} \times 100 \%$

Keterangan:

AS : persentase nilai rata-rata

$\Sigma S \quad$ : jumlah skor

Is $\quad$ : skor maksimal

Tabel 2. Kriteria Aktivitas Siswa

\begin{tabular}{cc}
\hline Rentang Nilai & Kriteria \\
\hline $80 \%<A S \leq 100 \%$ & Sangat Aktif \\
$60 \%<A S \leq 80 \%$ & Aktif \\
$40 \%<A S \leq 60 \%$ & Cukup \\
$20 \%<A S \leq 40 \%$ & Kurang Aktif \\
$0 \%<A S \leq 20 \%$ & Sangat Kurang \\
\hline
\end{tabular}

Dan untuk menggambarkan aktivitas guru dapat dilihat dari persentase nilai rata-rata yaitu sebagai berikut (Trianto, 2011).

$A G=\frac{\Sigma G}{\Sigma g} \times 100 \%$

Keterangan:

$A G \quad$ : persentase nilai rata-rata

$\Sigma G \quad$ : jumlah skor

$\Sigma g \quad$ : skor maksimal

Tabel 3. Kriteria Aktivitas Guru

\begin{tabular}{cc}
\hline Rentang Nilai & Kriteria \\
\hline $80 \%<A G \leq 100 \%$ & Sangat Baik \\
$60 \%<A G \leq 80 \%$ & Baik \\
$40 \%<A G \leq 60 \%$ & Cukup \\
$20 \%<A G \leq 40 \%$ & Kurang Baik \\
$0 \%<A G \leq 20 \%$ & Sangat Kurang \\
\hline
\end{tabular}

\section{HASIL DAN PEMBAHASAN}

Penelitian ini dilakukan dengan tujuan untuk mengetahui keefektifan desain pembelajaran ELPSA (Experiences, Language, Pictorial, Symbols, Application) ditinjau dari hasil belajar matematika siswa kelas VIII SMPN 1 Utan pada materi relasi dan fungsi tahun pelajaran 2020/2021. Sampel dalam penelitian ini adalah kelas VIII-1A yang terdiri dari 16 siswa. Karena sekolah menerapkan protokol kesehatan COVID-19, maka kelas VIII-1 yang awalnya berjumlah 32 siswa dibagi menjadi 2 kelas yaitu kelas VIII-1A dan VIII-1B yang masing-masing terdiri dari 16 siswa. Pertimbangan 
dipilihnya satu kelas sebagai kelas sampel melihat keterbatasan peneliti dengan keadaan pandemi COVID-19.

Penelitian ini dilaksanakan dalam empat kali pertemuan dengan tiga kali pertemuan untuk kegiatan pembelajaran dan satu kali pertemuan untuk pelaksanaan tes akhir (posttest). Untuk setiap pembelajaran dari pertemuan pertama sampai dengan pertemuan ketiga ketika proses pembelajaran berlangsung selalu dilakukan observasi aktivitas siswa dan guru. Observasi diamati langsung oleh observer (guru mata pelajaran matematika). Pada pertemuan keempat siswa diberikan tes akhir (posttest) untuk mengevaluasi pengetahuan siswa dan melihat hasil belajar matematika siswa. Instrumen yang digunakan tentunya telah memenuhi kriteria valid dan reliabel dengan tingkat reliabilitas tinggi.

\subsection{Hasil Pengujian Instrumen}

\subsubsection{Hasil Uji validitas}

Dalam penelitian ini, proses pengujian validitas yang dilakukan adalah pengujian validitas empiris. Validitas empiris dilakukan dengan melakukan pengujian butir soal kepada siswa kelas IX-2A SMPN 1 Utan tahun pelajaran 2020/2021 pada tanggal 17 November 2020 yang selanjutnya diolah dengan menggunakan program Microsoft Excel. Hasil pengujian validitas empiris dapat dilihat pada tabel berikut.

Tabel 4. Hasil Uji Validitas Empiris

\begin{tabular}{cccc}
\hline $\begin{array}{c}\text { Butir Soal } \\
\mathrm{N}=16\end{array}$ & $r_{x y}$ & $\alpha=0,05 ; d k=N-2$ & Keterangan \\
\hline $1 \mathrm{a}$ & 0,834 & 0,458 & Valid \\
$1 \mathrm{~b}$ & 0,834 & 0,458 & Valid \\
$1 \mathrm{c}$ & 0,781 & 0,458 & Valid \\
$2 \mathrm{a}$ & 0,717 & 0,458 & Valid \\
$2 \mathrm{~b}$ & 0,231 & 0,458 & Tidak Valid \\
$3 \mathrm{a}$ & 0,610 & 0,458 & Valid \\
$3 \mathrm{~b}$ & 0,492 & 0,458 & Valid \\
$4 \mathrm{a}$ & 0,597 & 0,458 & Valid \\
$4 \mathrm{~b}$ & 0,597 & 0,458 & Valid \\
5 & 0,598 & 0,458 & Valid \\
\hline
\end{tabular}

Berdasarkan hasil di atas dapat diketahui bahwa butir soal nomor $2 \mathrm{~b}$ memiliki nilai $r_{x y}<r_{\text {tabel }}$ sehingga butir soal tersebut tidak valid. Oleh karena itu, butir soal $2 \mathrm{~b}$ tidak digunakan sebagai soal tes akhir (posttest).

\subsubsection{Hasil Uji Reliabilitas}

Hasil pengujian reliabilitas dapat dilihat dalam tabel berikut. 
Tabel 5. Hasil Uji Reliabilitas

\begin{tabular}{ccc}
\hline$r_{11}$ & $\begin{array}{c}r_{\text {tabel }} \\
\text { Keterangan }\end{array}$ \\
\hline 0,838 & 0,458 & Reliabel \\
\hline
\end{tabular}

Berdasarkan hasil di atas, dapat diketahui bahwa nilai $r_{11}>r_{\text {tabel }}$ sehingga instrumen tes berkriteria reliabel dengan tingkat reliabilitas tinggi.

Setelah melakukan uji validitas, peneliti melakukan penelitian yang dilaksanakan pada tanggal 26 sampai dengan 28 November 2020. Berdasarkan penelitian yang telah dilaksanakan, kegiatan pendahuluan dimulai dengan guru membuka pelajaran, mengecek kehadiran siswa, menyampaikan tujuan pelajaran, serta mengaitkan materi yang akan dipelajari dengan pengetahuan yang dimiliki siswa menggunakan komponen E. Selanjutnya pada kegiatan inti, guru mengajukan beberapa pertanyaan yang berfokus pada bahasa/istilah spesifik yang digunakan siswa untuk membantu mengklarifikasi ide-ide tentang suatu konsep (komponen L). Tahap selanjutnya, guru mengarahkan siswa untuk bergabung dalam kelompok yang dibagi menjadi 4 kelompok, dimana dalam 1 kelompok terdiri dari 4 orang siswa. Setiap kelompok dibagikan LKS dan siswa aktif dalam kegiatan diskusi kelompok. Saat berlangsungnya diskusi, guru akan membimbing siswa yang mengalami kesulitan. Beberapa kelompok akan diminta untuk mempresentasikan hasil kerja diskusinya, kemudian guru dan siswa menanggapi dan membahas hasil pemaparan dari masing-masing kelompok. Pada tahapan ini saat pertemuan pertama komponen yang digunakan adalah komponen L dan P. Pada pertemuan kedua komponen yang digunakan adalah komponen $\mathrm{P}$ dan S. Dan pada pertemuan ketiga komponen yang digunakan adalah komponen A.

Pada kegiatan penutup, guru membimbing siswa untuk melakukan refleksi diri dan membuat kesimpulan terkait materi yang telah dipelajari. Guru meminta siswa untuk mempelajari materi pada pertemuan selanjutnya dan menutup pelajaran.

Setelah melaksanakan proses pembelajaran dalam tiga kali pertemuan, pada hari rabu 2 Desember 2020, peneliti melakukan tes akhir (posttest) di kelas VIII-1A yaitu sebanyak 16 siswa yang mengikuti tes. Selanjutnya peneliti melakukan pengoreksian terhadap lembar jawaban siswa untuk mengetahui nilai tes hasil belajar siswa. Peneliti menggunakan instrumen berupa tes dalam bentuk soal uraian. Dalam instrumen terdapat 5 butir soal mengenai materi relasi dan fungsi.

\subsection{Hasil Analisis Statistik Deskriptif}

\subsubsection{Ketuntasan Belajar Klasikal}

Berdasarkan hasil nilai posttest pada materi pokok bahasan relasi dan fungsi menunjukkan bahwa sebagian besar siswa memperoleh nilai di atas KKM $\geq 68$ yang dapat dilihat dalam tabel ketuntasan belajar klasikal sebagai berikut. 
Tabel 6. Analisis Ketuntasan Belajar Klasikal

\begin{tabular}{cccc}
\hline No & Ketuntasan Belajar & Jumlah Siswa & Persentase \\
\hline 1 & Tuntas & 14 & $87,50 \%$ \\
2 & Tidak Tuntas & 2 & $12,50 \%$ \\
\hline Total & 16 & $100 \%$ \\
\hline Rata-rata Nilai & \multicolumn{3}{c}{82,38} \\
\hline Nilai Tertinggi & 97 \\
\hline Nilai Terendah & 66 \\
\hline KKM & $\geq 68$ \\
\hline
\end{tabular}

Berdasarkan hasil di atas dapat diketahui bahwa sebanyak 14 siswa yang tuntas belajarnya atau sebesar 87,50\% (ketuntasan belajar klasikal) dengan nilai tertinggi yang diperoleh siswa yaitu 97. Dan terdapat 2 siswa yang nilainya tidak memenuhi KKM atau sebesar 12,50\% (ketuntasan belajar klasikal) dengan nilai yang diperoleh yaitu 66. Rata-rata nilai yang diperoleh kelas VIII-1A sebesar 82,38. Berdasarkan tabel 6 dapat digambarkan melalui diagram sebagai berikut.

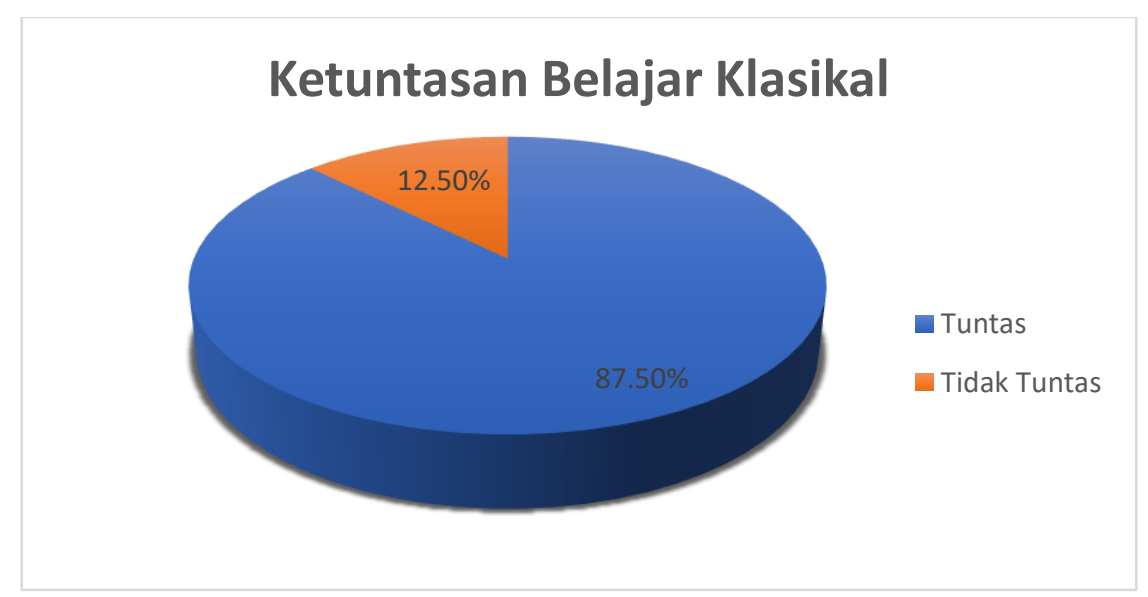

Gambar 1. Ketuntasan Belajar Klasikal

\subsubsection{Aktivitas Siswa}

Hasil observasi aktivitas siswa sebagai data penunjang dalam penelitian ini. Selama proses pembelajaran berlangsung observer (guru mata pelajaran matematika) mengamati dan mengisi lembar aktivitas siswa. Berikut ini adalah hasil analisis data dari lembar observasi aktivitas siswa.

Tabel 7. Analisis Observasi Aktivitas Belajar Siswa

\begin{tabular}{|c|c|c|c|c|c|}
\hline Pertemuan ke-n & $\begin{array}{c}\text { Skor yang } \\
\text { dicapai }\end{array}$ & $\begin{array}{c}\text { Skor } \\
\text { Maksimal }\end{array}$ & $\begin{array}{l}\text { Banyak } \\
\text { Indikator }\end{array}$ & Persentase & Kriteria \\
\hline Pertemuan ke-1 & 38 & 64 & 16 & $59 \%$ & Cukup \\
\hline Pertemuan ke-2 & 48 & 64 & 16 & $75 \%$ & Aktif \\
\hline Pertemuan ke-3 & 45 & 52 & 13 & $87 \%$ & Sangat Aktif \\
\hline \multicolumn{4}{|c|}{ Total Rata-rata } & $74 \%$ & Aktif \\
\hline
\end{tabular}


Berdasarkan tabel di atas dapat diketahui bahwa hasil observasi terhadap aktivitas siswa pada pertemuan pertama berkriteria cukup dengan persentase 59\%. Pada pertemuan kedua berkriteria aktif dengan persentase $75 \%$. Dari pertemuan pertama dan kedua dapat dilihat bahwa terjadi perubahan persentase aktivitas siswa. Hal ini dikarenakan pada saat pertemuan pertama siswa masih beradaptasi dengan desain pembelajaran ELPSA. Siswa juga masih malu dan ragu-ragu saat menjawab pertanyaan yang diberikan (komponen E) karena siswa belum mengenal guru. Selain itu, siswa juga sedikit kesulitan dalam memahami bahasa yang digunakan guru (komponen L). Saat pertemuan kedua aktivitas siswa berkriteria aktif, hal ini dikarenakan saat pembelajaran berlangsung siswa sudah berani memberikan umpan balik terhadap pertanyaan yang diberikan guru (komponen E) dan dalam kegiatan diskusi kelompok siswa juga terlihat sangat antusias.

Pada pertemuan ketiga aktivitas siswa berkriteria sangat aktif dengan persentase yang diperoleh yaitu 87\%. Dari pertemuan kedua dan ketiga juga terjadi perubahan persentase aktivitas siswa, hal ini dikarenakan saat proses pembelajaran siswa sudah mulai mengenal desain pembelajaran ELPSA dan siswa sangat antusias dalam kegiatan diskusi kelompok. Total rata-rata aktivitas siswa selama proses pembelajaran berkriteria aktif dengan persentase yang diperoleh yaitu $74 \%$.

Berdasarkan tabel 7 dapat digambarkan dengan menggunakan diagram sebagai berikut.

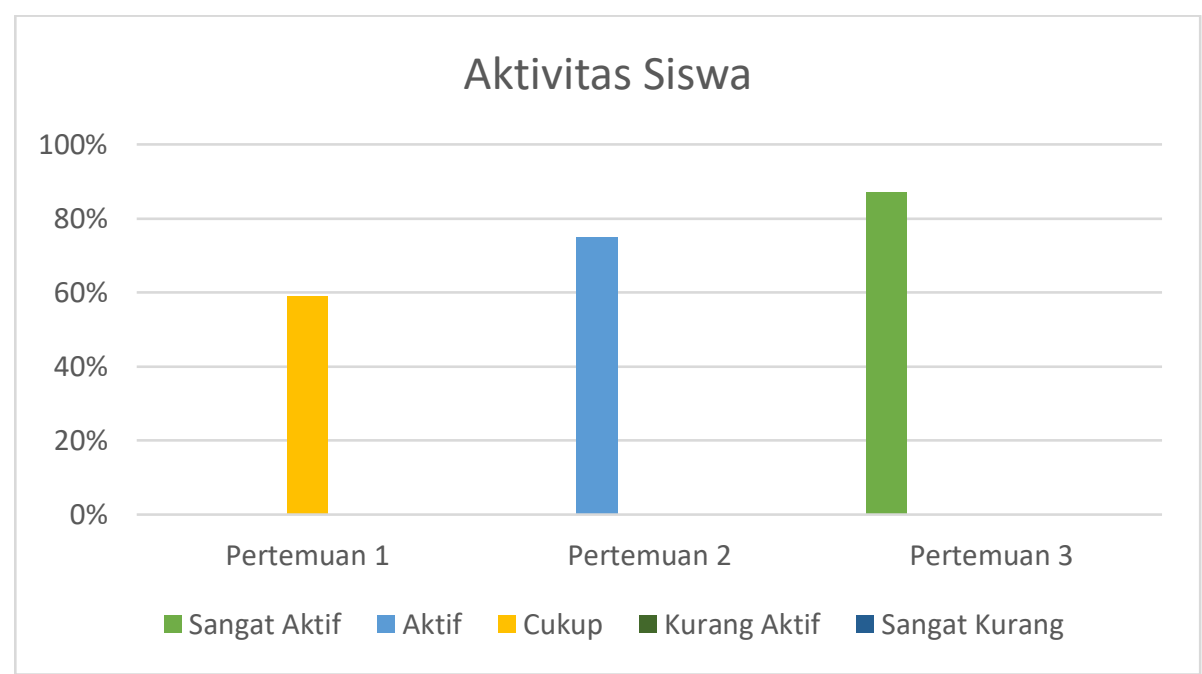

Gambar 2. Aktivitas Siswa

\subsubsection{Aktivitas Guru}

Hasil observasi aktivitas guru sebagai data penunjang dalam penelitian ini. Selama proses pembelajaran berlangsung, observer (guru mata pelajaran matematika) mengamati dan mengisi lembar aktivitas guru untuk melihat keterlaksanaan pembelajaran. Berikut ini adalah hasil analisis data dari lembar observasi aktivitas guru. 
Tabel 8. Analisis Observasi Aktivitas Belajar Guru

\begin{tabular}{|c|c|c|c|c|c|}
\hline Pertemuan ke-n & $\begin{array}{c}\text { Skor yang } \\
\text { dicapai }\end{array}$ & $\begin{array}{c}\text { Skor } \\
\text { Maksimal }\end{array}$ & $\begin{array}{c}\text { Banyak } \\
\text { Indikator }\end{array}$ & Persentase & Kriteria \\
\hline Pertemuan ke-1 & 54 & 90 & 18 & $60 \%$ & Cukup \\
\hline Pertemuan ke-2 & 65 & 90 & 18 & $72 \%$ & Baik \\
\hline Pertemuan ke-3 & 65 & 80 & 16 & $81 \%$ & Sangat Baik \\
\hline \multicolumn{4}{|c|}{ Total Rata-rata } & $71 \%$ & Baik \\
\hline
\end{tabular}

Berdasarkan tabel di atas dapat diketahui bahwa hasil observasi terhadap aktivitas guru pada pertemuan pertama berkriteria cukup dengan persentase $60 \%$. Pada pertemuan kedua berkriteria baik dengan persentase $72 \%$. Dari pertemuan pertama dan kedua dapat dilihat bahwa terjadi perubahan persentase aktivitas guru, hal ini dikarenakan guru melakukan perbaikan terhadap beberapa perilaku yang dinilai oleh observer seperti cara menyampaikan tujuan pembelajaran dan lebih sering memberikan kesempatan kepada siswa untuk bertanya. Selanjutnya, pada pertemuan ketiga juga terjadi perubahan aktivitas guru yaitu berkriteria sangat baik dengan persentase $81 \%$. Hal ini dikarenakan, guru melakukan perbaikan terhadap beberapa perilaku yang masih dirasa kurang. Total rata-rata aktivitas guru selama proses pembelajaran berkriteria baik dengan persentase yang diperoleh yaitu $71 \%$. Berdasarkan tabel 8 dapat digambarkan dengan menggunakan diagram sebagai berikut.

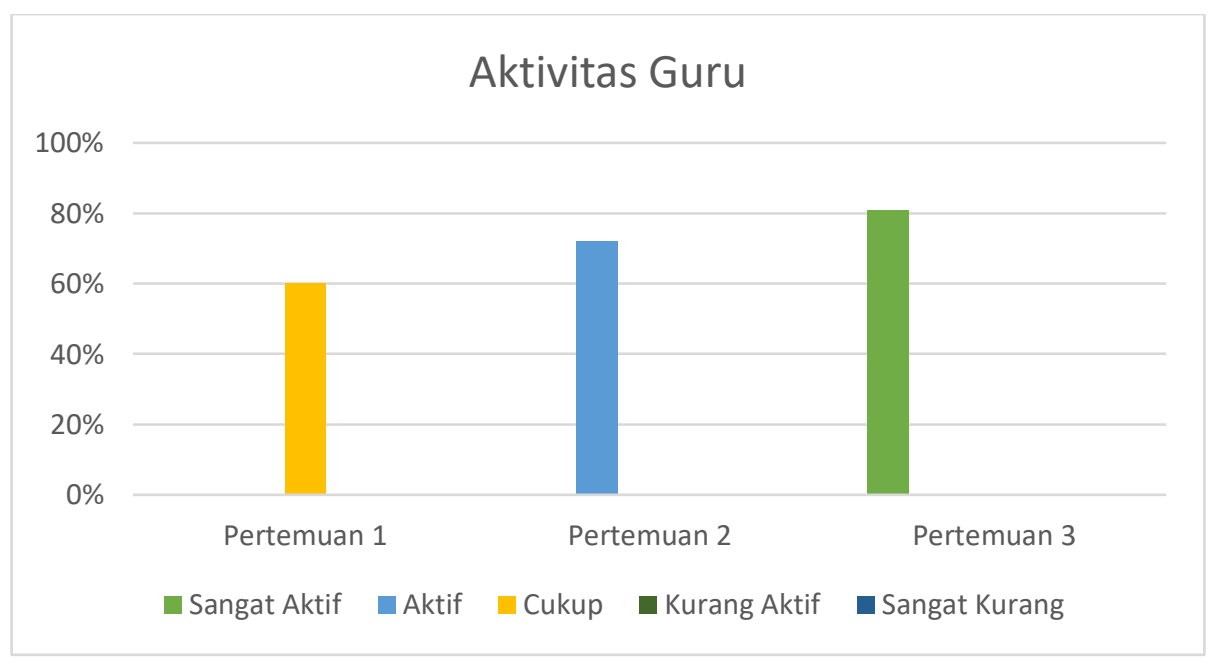

Gambar 3. Aktivitas Guru

Dari penjabaran di atas membuktikan bahwa penerapan desain pembelajaran ELPSA (Experiences, Language, Pictorial, Symbols, Application) dapat membuat proses pembelajaran menjadi lebih inovatif, menjadikan siswa lebih aktif dalam kegiatan pembelajaran dan pembentukan konsep siswa menjadi lebih baik sehingga dapat meningkatkan hasil belajar matematikanya. Selain itu, ketuntasan belajar klasikal dalam kelas tersebut telah tercapai sesuai indikator hasil belajar yaitu jika dalam kelas terdapat $\geq 85 \%$ siswa yang telah tuntas belajarnya. Selama proses pembelajaran aktivitas siswa mengalami perubahan persentase dengan kriteria aktif. Aktivitas guru 
juga mengalami perubahan persentase dengan kriteria baik yang menunjukkan bahwa proses pembelajaran telah terlaksana secara optimal. Oleh karena itu, dapat dikatakan bahwa desain pembelajaran ELPSA (Experiences, Language, Pictorial, Symbols, Application) efektif terhadap hasil belajar matematika siswa kelas VIII SMPN 1 Utan tahun pelajaran 2020/2021 dengan ketuntasan klasikal yang diperoleh sebesar 87,50\%.

\section{SIMPULAN}

Berdasarkan hasil dan pembahasan dapat disimpulkan bahwa desain pembelajaran ELPSA (Experiences, Language, Pictorial, Symbols, Application) efektif terhadap hasil belajar matematika siswa kelas VIII SMPN 1 Utan tahun pelajaran 2020/2021.

\section{REKOMENDASI}

Hasil penelitian ini adalah berupa gambaran kecil tentang desain pembelajaran ELPSA terhadap hasil belajar matematika siswa, sehingga selanjutnya dapat dilakukan pengembangan penelitian desain pembelajaran ELPSA pada materi dan sampel yang berbeda.

\section{REFERENSI}

Baidowi, Hikmah, N., \& Amrullah. (2019). Peningkatan hasil belajar matematika siswa kelas VIII SMPN 13 mataram tahun ajaran 2017/2018 melalui lesson study. Mandalika Mathematics and Education Journal (Vol. 1(1), pp. 2).

Depdiknas. (2004). Penilaian. Jakarta: Direktorat Pendidikan Nasional..

Emzir. (2017) Metodologi Penelitian Pendidikan: Kuantitatif dan Kualitatif. Depok: PT Raja Grafindo Persada.

Lowrie, T. \& Patahuddin, S.M. (2015). ELPSA-kerangka kerja untuk merancang pembelajaran matematika. Didaktik Matematika (Vol. 2(1), pp. 95).

Margono. (2004). Metodologi Penelitian Pendidikan. Jakarta: Rineka Cipta.

Sugiyono. (2019). Metode Penelitian Kuantitatif Kualitatif dan R\&D. Bandung: Alfabeta.

Trianto. (2011). Model Pembelajaran Terpadu. Jakarta: Bumi Aksara.

Dewi, W.A.F. (2020). Dampak covid-19 terhadap implementasi pembelajaran daring di sekolah dasar. Edukatif: Jurnal Ilmu Pendidikan (Vol. 2(1), pp. 56). 